\title{
Microfinance, Poverty Relief, and Political Justice
}

Miriam Ronzoni and Laura Valentini

\section{Introduction}

We live in a world in which a few are blessed with power and wealth and many others are crippled by poverty and powerlessness. This state of affairs is, without doubt, morally objectionable and in need of urgent remedy. Entrenched power asymmetries and global market forces, however, give the privileged both a vested interest in keeping things as they are and the ability to resist change. What is more, even when there is a will to initiate change, the road to eradicating poverty and institutional failures is paved with traps and vicious circles. Effective remedies must, therefore, be sensitive to real-world political and economic constraints.

A remedy seemingly satisfying this condition, which has gained popularity among political leaders and the wider public alike, is "microfinance." Offering financial services (particularly loans) to those who are too poor to access the traditional banking system looks like an excellent strategy for responding to world poverty in a way that is both empowering for the poor and economically efficient. Microfinance, that is, appears to promote development by exploiting, rather than countering, existing market mechanisms.

According to critics, however, microfinance institutions (MFIs) also have a “dark side:" they are ineffective at best, and exploitative at worst (Hulme 2000). Their purported ineffectiveness stems from their inability to reach the poorest of the

\footnotetext{
- We thank the reviewers of this piece, as well as Kimberley Brownlee, Luis Cabrera and Tom Sorell for helpful comments and suggestions.
} 
poor. Their alleged exploitative nature lies in MFIs often charging very high interest rates in order to be economically self-sustaining. Problematically, though, avoiding high interests turns microloans into quasi-donations, thus undercutting MFIs' capacity to take advantage of market mechanisms. Do these criticisms have merit? If so, should we conclude that microfinance is ill-suited to addressing the plight of the disadvantaged?

In this chapter, we argue that while these criticisms have bite when directed at existing MFIs, they do not suffice to disprove the potential of microfinance as a means of fighting global injustice. We agree with critics that some aspects of MFIs are problematic from a moral and/or financial point of view. We also agree that microfinance is an unlikely remedy for severe, life-threatening poverty, and therefore an inadequate vehicle for fulfilling the most immediate demands of humanity and global distributive injustice. However, we suggest that microfinance services, suitably restructured, may assist in tackling another, somewhat underemphasized, dimension of global injustice: the structural and political disempowerment of the world's poor. In short, we argue that MFIs might contribute to mitigating what we call political injustice.

Global disempowerment is, of course, connected to world poverty: poverty often breeds disempowerment, and disempowerment often breeds poverty. In order to tackle poor citizens' disempowerment with respect to both their own domestic institutions and global actors, arguably structural changes of the current global order need to occur. However, since such large-scale structural changes take time and their prospects of success are mixed, we suggest that intelligently planned microfinance projects might both offer a promising "second-best" solution and perhaps even help fuelling structural reform on a larger scale in the meantime. 
If microfinance projects are well designed, and if sufficient resources are regularly and reliably channelled towards them, they might contribute to the formation of a mid-level, economically active social group in developing countries - a group with a vested interest in making political institutions more "inclusive" and accountable, and with some power to do so. ${ }^{1}$ This, of course, requires significant changes to existing MFIs. The conclusion we reach is therefore tentative: Our claim is that the shortfalls of existing MFIs do not constitute a devastating blow to microfinance in principle. The potential of microfinance deserves to be explored further-particularly in connection with democratization, large-scale empowerment, and political justice. Whether existing shortfalls can be realistically overcome is, of course, a largely empirical matter that we cannot settle in the present paper.

Our argument is structured as follows. In Section 2, we offer a very brief overview of the history and workings of microfinance. In Section 3, we present three different perspectives from which the predicament of the poor can be addressed: humanity, distributive justice, and political justice. In Section 4, we consider whether microfinance represents a good response to humanitarian and distributivejustice concerns and answer in the negative. In Section 5, we turn to microfinance in relation to political injustice and argue — with caution and caveats — that, suitably reformed, it may constitute a helpful instrument to tackle disempowerment under our current, highly non-ideal circumstances. After considering, and responding to, a number of objections in Section 6, we conclude that if we wish to tackle political

\footnotetext{
${ }^{1}$ The classical argument that links the rise of a middle class to processes of democratization can be formulated in different and sometimes divergent ways. See Acemoglu and Robinson (2006, 221250). For the relevance of this divergence to our argument, see pp. 11-12 (note to production, insert right page numbers here). The link between the middle class and democracy has been amply discussed in political science (starting from Aristotle's Politics), and we cannot do justice to these discussions in the space available. For an overview, see Glassman (1995).
} 
injustice, we may have good reason to explore the potential of microfinance further, whilst remaining aware of the limitations of existing MFIs.

\section{What Is Microfinance?}

The very poor have traditionally been excluded from conventional banking, due to their inability to provide sufficient guarantees in return for loans. MFIs aim to remedy this exclusion, and extend access to banking services - especially credit, but also savings and insurance - to the socio-economically disadvantaged.

Behind the development of microfinance, as already noted by other contributors in this volume, lies the vision of Muhammad Yunus, an economist from Chittagong University, in Bangladesh. In 1983, Yunus officially established Grameen Bank, with the aim of providing loans to poor Bangladeshi men and women, thereby freeing them from dependence on, and exploitation by, local moneylenders. Yunus was convinced that, through microfinance, "millions of small people with their millions of small pursuits can add up to create the biggest development wonder" (Grameen Communications 1998). In 2006, Grameen Bank and Yunus jointly received the Nobel Peace Prize, "for their efforts to create economic and social development from below" (Nobel Media AB 2014). As of 2011, the bank has provided credit to over eight million people in Bangladesh, especially women (Grameen Communications 1998; see also Perkins 2008).

Since the establishment of Grameen Bank, many other microfinanceespecially microcredit—institutions have emerged around the world, including in Africa, Asia, Latin America and Canada (Morduch 1999, 1569). Although generalizations are always tricky, there are a number of features that often 
characterize MFIs, and set them apart from more traditional financial service providers.

Subsidy-dependency: Many — though not all-MFIs rely on subsidies in order to cover their operational costs and to keep their interest rates on loans sufficiently low. Although in recent years there has been a strong push towards selfsustainability, a good number of MFIs still need to count on donor subsidies for their continued existence (Hermes, Lensink, and Meesters 2011).

Integration of financial services and broader social services: Unlike traditional banks, some MFIs — often attached to NGOs — are not solely devoted to the provision of financial services, but integrate such provision with broader "social intermediation services such as group formation, development of self-confidence, and training in financial literacy and management capabilities" (Ledgerwood 1998, $1)$.

Lending without collateral: Microlending institutions typically do not ask for collateral in case of defaults on repayments. Collateral would in fact prevent many of their target clients, who typically have very few if any possessions, from being eligible for credit in the first place. Instead of insuring themselves against defaults on repayments, MFIs often try to maximize repayment rates, for example, by initiating repayment soon after loans have been granted, or by relying on special lending mechanisms such as group loans. These loans are given out to groups rather than single individuals, with the effect that members pressure each other into keeping to the envisaged repayment schedule (Ledgerwood 1998, 70; see also Morduch 1999). ${ }^{2}$

\footnotetext{
${ }^{2}$ In this volume, see especially the chapters by Sherratt and Marr.
} 
MFIs are thus sui generis financial service providers, whose structure and modus operandi make them fit for extending access to credit (as well as savings and insurance) to low-income households which have typically been excluded from access to banking services. MFIs might look like the "silver bullet that will cure world poverty and spread the wealth-creating force of capitalism across the globe" (Perkins 2008). But is such optimism warranted? Can MFIs really remedy some of the most morally objectionable aspects of the world in which we live?

\section{Three Perspectives on the Moral Failures of Today's World}

As we mentioned at the outset, our world is marked by poverty, inequality, and disempowerment for a large portion of its population. The perspectives from which we might address this ethically troublesome state of affairs are multiple. In what follows, we consider three in particular: humanity, distributive justice, and political justice.

\subsection{Humanity}

Consider, first, the perspective of humanity. Morally decent persons cannot remain indifferent to the suffering of fellow humans. Whenever others are in need, and we can assist them at little cost to ourselves, we have a moral duty to do so. From this perspective, it is wrong to hold on to resources that for us are superfluous, when we can use them to alleviate others' misery. Humanity places a duty on us to help needy strangers using what we rightfully possess (we here follow B. Barry 1991; see also Valentini 2013).

To see the force of this duty, it is worth recalling its perhaps most eloquent defence, offered by Peter Singer over 30 years ago. Singer invites us to imagine 
finding ourselves in the proximity of a shallow pond where a child is drowning. Saving the child would cost us very little: a few minutes and the bother of getting our clothes wet. Even though we are rightfully entitled to both our time and our "dry clothes," it would be morally unacceptable to refuse to pull the child out of the water. The urgency of the child's predicament, coupled with the relative ease with which we could perform the rescue, obligates us to use our time and resources to save him (Singer 1972; cf. Fabre 2002). ${ }^{3}$

By analogy, if we can save many people's lives simply by writing a cheque to Oxfam, or donating to other charities and NGOs, we are under a moral duty to do so (Singer 1999). Even if the resources we would devote to these projects are our own, we cannot keep hold of them and retain a clear conscience. Doing so would constitute a breach of humanity.

\subsection{Distributive Justice}

Humanitarian duties require that we help the needy using our own resources. But what if we are not entitled to the resources in our possession, and these rightfully belong to the needy? To answer this question, we must turn to the perspective of distributive justice - namely the branch of political morality that concerns the distribution of entitlements across agents.

Predictably, there is a multiplicity of competing accounts of distributive justice. For the sake of simplicity, we focus on two in particular, which arguably lie at the opposite ends of the distributive-justice spectrum. One targets relative deprivation, and holds that nobody should be worse off through no fault of their own

\footnotetext{
3 Though Singer, as a utilitarian, is unlikely to place as much emphasis on the distinction between duties of humanity and duties of justice (the latter giving rise to entitlements).
} 
(responsibility-sensitive egalitarianism). The other targets absolute deprivation, and holds that every human being is entitled to enough resources to lead a decent life (sufficientarianism). ${ }^{4}$

No matter which end of the "distributive-justice" spectrum we considerwhether egalitarian or sufficientarian - the distribution of resources in the world today must be condemned as seriously unjust. While some (especially in the West) have access to plenty of resources, others are virtually doomed to a life of misery; and this through no fault of their own. Relative and absolute deprivation are both widespread in the world today.

From the standpoint of distributive justice, we therefore ought to restructure the global pattern of holdings - either in order to equalize life prospects between the wealthy and the needy, or in order to give the latter a sufficient bundle of resources to lead decent lives. If we take the perspective of distributive justice seriously, we must conclude that we are not entitled to all of the resources in our possession; some of them belong to the world's poor (B. Barry 1991). Our duties towards them are not a "mere" matter of humanity, but first and foremost an imperative of distributive justice (Pogge 2008; Valentini 2011).

\subsection{Political Justice 5}

Finally, let us consider the perspective of political justice. Compared to distributive justice, political justice operates at a deeper level, focusing on the power structures that determine what people's entitlements are. A social system is politically just only if power relations within it are not excessively asymmetrical, if nobody is subject to

\footnotetext{
${ }^{4}$ For the former, see Lippert-Rasmussen (2013) and Caney (2005); for the latter, see e.g., Brock (2009) and Blake (2001).

${ }^{5}$ For general discussion see Macdonald and Ronzoni (2012).
} 
the arbitrary will of a few powerful actors. ${ }^{6}$ For instance, while a society with a perfectly just distribution of resources governed by a benevolent dictator would be unobjectionable from the standpoint of distributive justice, it would be problematic from that of political justice. Why? Because, in such a society, the citizenry would be entirely dependent on the will of a powerful individual.

If we take political justice seriously, what is morally problematic about the global order is that it breeds disempowerment and structural dependence, either directly or by contributing to domestic political injustice (Ronzoni 2012). An example of the former is arguably offered by WTO negotiations, where — at least until recently_-wealthy nations could take advantage of their superior bargaining power and secure unfairly advantageous terms of trade vis-à-vis developing countries (see, e.g., Stiglitz 2006; Moellendorf 2005; Steinberg 2002; Grewal 2008, 95). Other forms of direct political injustice involve the IMF and the World Bank. As Ngaire Woods and others argue, these institutions intrude in the recipients' most important policy decisions by placing strict conditions on the aid they offer (Woods and Narlikar 2001). What is more, their criteria of conditionality are often aimed at promoting policies that please powerful shareholder nations, while failing to address the special needs of borrower countries (Woods 2006). For instance, by making aid conditional on the implementation of neoliberal policies, the IMF and the World Bank undermine fragile countries' ability to build robust domestic schemes of labour and social protection.

The existing international order contributes to disempowerment also indirectly, by creating perverse incentives at the domestic level. For instance, as Thomas Pogge and others have argued, internationally accepted rules such as the

\footnotetext{
${ }^{6} \mathrm{Cf}$. the notion of republican freedom as defined in Pettit (1997).
} 
International Borrowing Privilege and the International Resource Privilege, make the prospect of seizing power in resource-rich countries particularly attractive, by giving any de facto leader the authority to borrow and dispose of resources on the country's behalf (Pogge 2008, 118-121; 159-173; Pogge 2002). Other examples of indirect political injustice include harmful labour and tax competition which, some argue, heavily constrain states' ability to implement fiscal and labour protections (see, e.g., Dietsch 2011; Avi-Yonah 2008; C. Barry and Reddy 2008). This results in disempowerment not only for states, but also for many of their citizens, who are exposed to high levels of social vulnerability due to the absence of appropriate social policies. The institutions that apply to them are not under their control.

Given the nature and causes of political injustice, addressing it requires that the rules governing the global order, and the power-structures underlying it, be reconfigured so as to allow each society to be genuinely self-determining, both internally (i.e., under the control of its citizens rather than of ruthless dictators) and internationally (i.e., not subject to the will of the most powerful nations).

Institutional reform is of course complex to achieve but, when it comes to realizing political justice, it is also unavoidable.

\section{Microfinance, Humanity, and Distributive Justice}

In the previous section, we have looked at three perspectives from which to evaluate the moral failures of the contemporary international order. In this section, we consider whether supporting MFIs is a good way of satisfying the demands of humanity and distributive justice in particular. We turn to political justice in the next one. 


\subsection{Microfinance and Humanity}

Duties of humanity demand that we help the needy by donating some of our own resources, so long as this is not excessively costly to us. The language of donation resonates quite well with the practice of microfinance. As we have seen, MFIs often rely on subsidies to cover their start-up costs and ensure the continued provision of credit to the poor at low enough interest rates. Those who subsidize MFIs are typically labelled "donors." Implicit in this label is the idea that these agents are acting on duties of humanity, using their own possessions to help the needy and destitute. But is microfinance a good way of discharging our humanitarian obligations? Probably not.

To understand why, let us consider duties of humanity more closely. These may be discharged in a variety of ways, including donations to charities, involvement in development projects, distance adoption and so forth. Although the bearers of duties of humanity have some latitude in deciding how to discharge them, the urgency of recipients' needs appears to be a key consideration in well-conducted deliberations (cf. B. Barry 1991). To see this, consider an agent, X, faced with two needy strangers: $\mathrm{Y}$, who is about to starve, and $\mathrm{Z}$, whose standard of living is rather low but whose life is not at risk. As it happens, $\mathrm{X}$ can only assist one of them at reasonable cost to himself. That is, he can either save Y's life, or improve Z's standard of living. Although $\mathrm{X}$ is at liberty to choose whom to help, in these circumstances, choosing to help Z rather than Y seems morally sub-optimal. Appropriate reflection on the aim of duties of humanity should lead $\mathrm{X}$ to direct his assistance towards $\mathrm{Y}$, whose needs are most urgent.

At this point, it is crucial to distinguish humanity from supererogatory generosity (see Buchanan 1987). The latter also involves helping others, but goes 
above and beyond what is required by duty. Donations to museums and art galleries, for instance, arguably fall within the realm of supererogation. Such donations help others by making valuable cultural experiences more easily accessible to them, but the interests they advance do not seem weighty enough to give rise to moral requirements. Duties of humanity, by contrast, are distinctive in that they target those who are most in need of help, and whose fundamental interests are at stake. They "kick in" in circumstances where some fellow humans are so badly off that we - the relatively well off — cannot say to have fulfilled all our moral obligations even if they do not have any justice-based entitlements against us.

These reflections allow us to understand why supporting MFIs is probably not a good way of discharging our humanitarian duties — namely, because MFIs do not target the very poor, whose needs are most urgent (Barres and Lard 2007, 5657). The very poor, whose most basic needs are unmet, rarely think about the possibility of taking out a loan, let alone of establishing a small business. Setting up an economic activity is a meaningful long-term project, which we normally consider only when our immediate, short-term needs are met. Moreover, the extremely poor lack the resources to comply with the early repayment schedules that, as we have seen, MFIs often adopt in order to avoid charging high interest rates and asking for collateral. Finally, although MFIs might help the very poor indirectly, for instance, by funding businesses that could then offer them jobs, or through trickle-down effects of increased societal wealth, it is not clear why-from the perspective of humanity—we should take the risk rather than help the very poor directly (Zeller and Johannsen 2008, 228). Why gamble with the lives of the needy, if there are alternative forms of aid that can effectively and more reliably address their predicament? 
If this is correct, supporting MFIs may not be the best way to fulfil our duties of humanity. To fulfil them, we have more reason to channel our resources towards forms of aid that tackle the very poor directly.

\subsection{Microfinance and Distributive Justice}

Let us now examine whether supporting MFIs fits well with the demands of global distributive justice — whether sufficientarian or egalitarian. ${ }^{7}$ Before addressing this issue, however, one point must be made clear: Whether or not MFIs are conducive to global sufficiency or global equality, supporting them will necessarily be a second-best solution. Why? Because, if we believe that the distribution of resources across the world is unjust, then we must also believe that it ought be structurally altered, by way of unconditional transfers of property or even through the establishment of just global institutions. ${ }^{8}$ Justice is done by changing patterns of holdings, not through aid and donations. Still, if large-scale structural changes are unlikely to occur in current political circumstances, a good way of fulfilling at least part of our duties of justice could involve compensating the victims of unjust structures through "donations"” to development projects. ${ }^{9}$

Having said that, our specific question still stands: Are MFIs, among all aid programmes we may support on grounds of justice under non-ideal circumstances, a good choice? While it is true that aid in general fails to question the very legitimacy

\footnotetext{
${ }^{7}$ For the sake of completeness, we should mention that, according a third prominent paradigm of distributive justice, namely prioritarianism, what matters is whether a distributive scheme gives priority to the worst off. MFIs would be obviously problematic from a prioritarian perspective, because they fail to target the worst off. For an account and defence of prioritarianism, see Parfit (1997) and Arneson (2000).

${ }^{8}$ For a more in depth reflection on the non-ideal and second-best nature of microfinance as a remedy to global distributive injustice, see Daniel Butt's chapter in this volume.

9 The idea that economic contributions to development projects can be construed as a form of compensation for global injustice was first suggested by Thomas Pogge, according to whom citizens of affluent countries are implicated in the human-rights violations perpetrated by the global order and powerful states. See, for instance, Pogge (2005).
} 
of the current global pattern of holdings, MFIs are particularly problematic in this respect, because they operate on the presupposition that citizens of affluent countries (i.e., the most likely potential lenders) are entitled to what they currently own. Otherwise, how could poor recipients of loans be asked to pay back what they receive, and with interests?

This objection does not necessarily entail that microfinance is wholly unjustified in the highly non-ideal circumstances of our world. It may be empirically true that (i) the best way of getting out of poverty is to secure a sustainable way to make a living, rather than becoming structurally dependent on aid, and (ii) taking up responsibility to pay back a loan might be a good strategy for avoiding the traps and vicious circles that poverty causes. Yet, as Daniel Butt has eloquently argued in his contribution to this volume, those who think that the global pattern of holdings is unjust must recognize that microfinance has a somewhat paradoxical moral pedigree. On the one hand, it might constitute an effective means of escaping poverty traps. On the other hand, if the world's poor are unjustly put in such traps to begin with, and lenders are partly responsible for this injustice, how can we consistently hold that the poor have an obligation to repay their debt?

Moreover, and perhaps more importantly, MFIs may not be ideal instruments of distributive justice and, for the very same reason, they disappoint as vehicles of humanitarian action: They do not target the very poor. As Jonathan Wolff and Avner de Shalit point out, both egalitarians and sufficientarians converge on considering the very worst off as the highest priority on the distributive agenda, as they are both those who most clearly do not reach sufficiency levels and those who most strongly suffer due to the unequal structure of global holdings (Wolff and de-Shalit 2007, 
155-166). ${ }^{10}$ If we want to reduce inequalities or bring people up to sufficiency, we have to start by targeting the very poor and, as we have seen, MFIs fail to do this.

True, not all interpretations of sufficientarianism or egalitarianism claim that targeting the very poor should be our first priority. Paula Casal, for instance, argues that sufficientarians may well be committed to targeting those who are just below but not significantly below the sufficiency level, because this allows us to bring more people up to sufficiency (Casal 2007). This interpretation of sufficientarianism fits MFIs, since they are likely, if successful, to bring poor but not desperately poor people up to decent standards of living. However, Casal highlights this point precisely to show the implausibility of sufficientarianism, when conceived of along these lines. Arguably, a theory that cares about people having enough cannot plausibly be more interested in lifting a higher number of people above the threshold (regardless of what happens to the very worst-off) than in getting as many destitute individuals as close as possible to the threshold, even if still below it. ${ }^{11}$

Similarly, according to a very prominent approach to measuring inequality, calculated through the Gini coefficient, inequality of $\mathrm{X}$ decreases through general dispersion of $\mathrm{X}$ across the population, and not necessarily by improving the fate of the worst-off. ${ }^{12}$ Assuming this mode of measurement, if a large number of poor people, but not the poorest, are brought up towards the middle income level, this reduces inequality more than helping a smaller number of extremely poor individuals. That said, the Gini coefficient, although very prominent, is not an

\footnotetext{
${ }^{10} \mathrm{We}$ are here assuming, for the sake of simplicity, that the worst off cannot plausibly be held responsible for their predicament.

${ }^{11}$ Casal $(2007,298)$ argues that some sufficientarian positions might be committed to raising people above sufficiency at the cost of further worsening the conditions of individuals who would be below the threshold anyhow.

${ }^{12}$ According to the Gini coefficient, maximal inequality occurs when, in a given society, one person holds the entirety of the income; while perfect equality occurs when the income is equally distributed across the population.
} 
uncontested way of measuring inequality. ${ }^{13}$ Moreover, even if we were to accept it as a good way of measuring inequality, it is unclear that this would necessarily have the normative implication that we should not target the very poor first; indeed, the intuitive grip of Wolff's and De Shalit's claim that egalitarians should care first and foremost about those who are at the very bottom seems hard to defeat.

In sum, then, MFIs do not seem to be ideal instruments for tackling global distributive injustice. Development aid does not deliver the restructuring of holdings that distributive justice requires, and MFIs less so than other aid programmes, because they are based on loans that have to be paid back. Moreover, MFIs fail to target the very worst off, and this seems, on balance, to be a problem for both sufficientarian and egalitarian accounts of distributive justice.

\section{Microfinance and Political Justice}

Recall that political justice focuses on the power structures characterizing both the domestic and the international arena. A politically just world is one in which individuals and/or political communities are not victims of domination that makes them unable to shape their lives and futures. As seen above, from the perspective of political justice, the power structures currently characterizing the international arena are unacceptable. What is more, the world's privileged arguably contribute to their continued existence — by either actively supporting, or at least acquiescing with, the political measures and institutions that reinforce them (Pogge 2008, 18-26, 118$122,145-150)$. For the purpose of this chapter, we broadly accept these arguments, and ask: If the world is politically unjust, are MFIs a good way to address its injustice?

\footnotetext{
${ }^{13}$ For a discussion of different ways of measuring inequality, see Sen and Foster (1997, 24-46).
} 
Let us look more closely at our co-responsibility for the politically unjust features of the current global order. As we argued in Section 3.3, global political injustice gives rise to the disempowerment of both fragile countries and individuals. Some forms of global political injustice cause disempowerment directly, such as when powerful countries dominate weaker ones by imposing unfair conditions of cooperation (for instance on trade) or by shaping international institutions in ways that mirror their own interests rather than official development agendas. Other forms of political injustice, by contrast, cause disempowerment indirectly, by creating perverse incentives at the domestic level and contributing to making societies internally unjust, unstable, less responsive to citizens, and more prone to civil strife.

As in the case of distributive justice, ending political injustice requires us to change structural features of the global order. In this case, however, they are structures of global social power rather than patterns of holdings. The analogy continues: when we fail to support just reforms or to fight injustice, or when creating new institutions seems an unlikely prospect, we should at least indirectly compensate the victims of our involvement in an unjust global political and economic system, for instance by donating to well-run development agencies and NGOs. In the case of political, rather than distributive, justice, this means that we should donate more and donate particularly to development projects that aim at empowerment. We suggest that, if this is our aim, we have reasons to support microfinance projects, because they target disempowerment specifically.

This may look like an ill-judged suggestion. After all, political justice is a public issue par excellence, to be addressed by establishing better institutional structures and making power accountable — not by supporting development projects. We are sensitive to this worry. However, when public means to end or reduce global 
political injustice seem out of reach, a second-best option might be to support development projects that aim at making the powerless better equipped to both fight injustice, and shape their institutional environment, thus reducing domination. MFIs, in particular, might be a good empowerment tool to the extent that they succeed in achieving the following two goals:

A. Reducing the short-term disempowerment of their specific addressees;

B. Reducing the long-term disempowerment of society more broadly.

$A$.

The beneficiaries of MFIs are given the opportunity to free themselves from poverty and aid-dependence, thereby acquiring control over their lives and projects. ${ }^{14}$ Moreover, the structure of lending of well-designed MFIs makes its beneficiaries less vulnerable qua economic actors, because their source of funding is normally not linked to high interest rates, which might lead them to incur further debts and fall into debt-traps, and less dependent on the local financing sector, which, in fragile countries, is typically precarious and corrupt.

Having said that, in order to have these positive effects, MFIs must be structured in ways that significantly differ from many current microcredit projects in three respects: they must (i) rely on more resources, (ii) guarantee more continuity, and (iii) be more sensitive to local obstacles. First and foremost, more money has to be invested into MFIs, and this is precisely what this paper suggests should be done. Without adequate support from would-be donors, MFIs cannot realize their full potential as empowerment strategies. Second, microfinance projects must guarantee

\footnotetext{
${ }^{14}$ For evidence of the empowering effects of microfinance, especially on women, see Pitt, Khandker, and Cartwright (2006) and Sanyal (2009).
} 
continuity where they operate, if they truly wish to reduce disempowerment and vulnerability in the long term. Third, microcredit activities have to be monitored more carefully, be evaluated in the wider social context in which they are to be implemented, and be made impervious to perverse incentives. Microloans, for instance, can potentially make poor economic actors less dependent on local organized crime and moneylenders. However, for this goal to be achieved, crime infiltrations have to be specifically targeted. Otherwise microcredit funds run the risk of being used to pay protection money, local moneylenders, and even to generate new illegal moneylending practices to help people repay their microloans (see, e.g., Mallick 2012; Gokhale 2009). Insufficient funds, lack of continuity, and lack of sensitivity towards local obstacles are common structural flaws of several current microfinance projects - but not, we suggest, intrinsic flaws of the microfinance agenda as such. ${ }^{15}$

$B$.

If sufficiently robust, MFIs can reduce the long-term disempowerment of the societies of which their addressees are members. Microfinance networks can be effective not only as instruments to fight poverty (although, as we have seen, not extreme poverty directly), but also as means to promote small business. This means that, in the long run, MFIs can support the rise of an economically active social class that has both a vested interest in having more stable, more accountable, and less corrupt political institutions, and some power to advance political demands.

\footnotetext{
${ }^{15}$ This also would hold for such incidents as Norway's investigation into allegations that Yunus' Grameen Bank diverted aid money from the Norwegian International Development Ministry, as well as from Sweden and Germany, to another Grameen entity not involved in microlending. See Anbarasan (2010).
} 
This becomes particularly evident if one pays attention not only to microcredit but also to schemes of microsavings and microinsurance. Savings and insurance schemes are risk-management tools whose aim is to allow beneficiaries to make plans, take risks, and become active players in civil society. Reliance on savings and insurance schemes is typical of the middle class which, unlike the economic élites, cannot rely on independent wealth, but which can plan and take risks in a way that the very poor cannot. If implemented effectively, and bearing in mind the three caveats of sufficient resource availability, continuity, and contextsensitivity outlined above (we are not, it is worth repeating, supporting existing MFIs), microcredit, microsavings and microinsurance might jointly contribute to the rise of an economically active, and therefore politically demanding, class in poor countries

This, we suggest, would be a good remedial way of discharging our duty to reduce political injustice, by encouraging bottom-up empowerment. Why so? Because a "middle class," conceived along the lines suggested above, is widely considered a key factor in the creation not only of economic prosperity, but also of institutional stability and political accountability (see, e.g., Glassman 1995; Barro 1999). The middle class has an interest in political accountability and in stable rules to guarantee smooth business; moreover, unlike the very poor, it has some social power to further its interests. Members of the middle class place more demands on, and expect more from, their politicians. This is why the middle class is often considered a leading force in democratization processes (Acemoglu and Robinson 2006). ${ }^{16}$ Therefore, if we recognize a responsibility to end global political injustice,

\footnotetext{
16 Admittedly, however, some authors suggest that the connection between the middle class and democratization is not universal. See, for instance, Jones (1998).
} 
and believe that our ability to change global political structures directly is significantly limited, supporting (suitably reformed and restructured) MFIs might be a good second-best solution.

One important caveat is essential at this point. At first sight, one might get the impression that our claim concerning the potential positive impact of microfinance on political justice, via the rise of an economically active middle class, presupposes the empirical assumptions of classic modernization theory (Lipset 1959). According to theories of modernization, democracy and institutional reforms, although absent at the early stages of economic development of a given society, will come naturally once growth and prosperity have reached a certain level. Once a prosperous middle class is in place, democracy will soon or later follow. This seems to suggest that even those who care about democracy need not worry if countries pursue development through authoritarian and oppressive means to begin with.

Daron Acemoglu and Jim Robinson (2012), however, have recently advanced a powerful challenge to the empirical findings of modernization theory. They offer detailed empirical evidence to support the claim that both prosperity and democracy are the outcome of getting one's institutions right. Their analysis suggests that development requires "inclusive," rather than "extractive" institutions, where both kinds of institutions have a political as well as an economic dimension. Inclusive institutions empower people across society-political ones by guaranteeing the rule of law and by striking the right balance between centralization and devolution; economic ones by ensuring widespread participation in economic opportunities (through securing property rights, widespread access to the market, the prevention of monopolies, etc.). By contrast, extractive institutions - often the complex legacy of colonialism — systematically privilege (although in a range of 
different ways) specific groups or elites. When societies manage to move from more extractive to more inclusive institutions, in economic as well as in political terms, both prosperity and full-blown democratization often follow. The failure of a lot of development work, in Acemoglu's and Robinson's view, is due to development institutions overlooking this important point and focusing on growth instead-as well as to the brute fact that it is extremely difficult for a society that has deeply entrenched extractive institutions, as a lot of former colonies do, to get rid of them (Acemoglu and Robinson 2012).

Our argument concerning the potential of microfinance is perfectly compatible with this institutionalist perspective. The various instruments of microfinance, when restructured along the lines we have suggested, can be seen as an attempt to move to a more "inclusive" set of economic rules, which give access to economic opportunities to a wider segment of society. Microfinance, in a way, can be seen as itself a form of inclusive economic institution. What is more, if Acemoglu and Robinson are right in arguing that economically and politically inclusive institutions are mutually reinforcing, and if we want politically inclusive institutions (as political justice requires), fostering the development of a social group capable of demanding them is a good way of working towards that goal.

Finally, to link up this point to the conclusion we reached at the end of the previous section, it should be noted that promoting political justice might also have a positive effect on distributive injustice. As Amartya Sen $(1983 ; 1999 ; 2000)$ has argued, politically accountable structures of power are much less likely to tolerate extreme domestic deprivation than other regimes, and are often more capable of addressing it. Therefore, although our claim is that the best prospects for MFIs as "development tools" concern the fostering of political justice, one must, as we noted 
at the beginning of this chapter, always be attentive to the mutually reinforcing relationship between poverty and disempowerment—and conversely, between political and distributive justice.

\section{Objections}

Having suggested that microfinance offers a possible second-best response to the problem of global political injustice, we now consider three worries that might be raised in relation to our argument, namely, that MFIs create perverse incentives; that MFIs will fail to promote the rise of a middle class in developing countries; and that MFIs cannot be both self-sufficient (i.e., not dependent on subsidies) and nonexploitative.

\subsection{Perverse incentives}

A first concern is that supporting MFIs might generate the type of perverse incentives often associated with development aid. Paradoxically, aid programmes that succeed in alleviating poverty may (i) breed passivity on the part of the disadvantaged, making them less prone to acknowledging and criticizing their governments' deficiencies and, relatedly, (ii) breed complacency on the part of governments themselves (Bräutigam 2000).

Examples of this phenomenon are offered by Emergency Social Funds, such as those established in Bolivia and Peru in the late eighties and early nineties. These were primarily aimed at mitigating the adverse impact of Structural Adjustment Programmes on the poorest segments of these countries' populations. However, as Christine Whitehead $(1995,53)$ explains, the Funds were also "designed to reduce the potential political unrest ensuing from adjustment, and so to ensure acceptance 
of [liberalizing] economic reform."

Like development aid, MFIs aim at alleviating poverty and often rely on donor subsidies. In light of this, one could reasonably worry that, if MFIs were successful in their mission, they too could have the effect of "buffer[ing] societies from some of the costs of bad governance and reduce their incentive to press for change and greater accountability" (Bräutigam 2000, 26). ${ }^{17}$

If our argument is correct, however, this concern should be significantly weaker in the case of MFIs. Although many of them rely on donor subsidies and strive to ameliorate the conditions of the poor, their modus operandi arguably insulates them from these types of perverse incentives. Instead of "handing out assistance" from the top down, MFIs are designed to give their low-income customers the opportunity to help themselves. Far from breeding passivity, access to financial services can incentivize entrepreneurship, make the poor better able to cope with fluctuating economic conditions, and in so doing allow them to take more responsibility for how their lives go.

Moreover, by potentially decreasing the economic vulnerability of the poor and increasing their independence, MFIs place them in a better position to press for institutional change and hold their governments to account. While the starving might neither be able to, nor particularly interested in, political participation, members of an emerging middle class have both the resources and motivation to insist that governments attend to their interests.

Of course, this conclusion only holds on the basis of our optimistic hypothesis that support for MFIs can generate a virtuous circle, and facilitate the development and strengthening of a middle class in developing countries. But what

\footnotetext{
${ }^{17}$ In the original, the quoted passage refers to aid in general, rather than microfinance specifically.
} 
if this optimism is misplaced?

\subsection{Effectiveness}

Our argument rests on the normative assumption that we are partly responsible for global political injustice, and that supporting MFIs can be a good second-best way of honouring our responsibilities when our capacity to contribute to structural changes is limited. The argument, however, depends on two mutually connected empirical assumptions that we cannot fully defend here (we are, after all, making a normative argument): First, that MFIs, suitably reformed, might help promote the rise of the middle class in fragile countries; second, that a sizeable middle class is a crucial factor for institutional stability, the rule of law, political accountability, and democracy. Are these two assumptions sufficiently robust?

We shall not discuss the second connection, as we find the link between widespread economic participation across different groups in society and accountability/democratization sufficiently established in the literature. It is not, of course, entirely uncontroversial, but any argument proposing a specific recipe for development will have to rest on a somewhat controversial empirical theory, and our argument is no exception.

The first link — between MFIs and the rise of the middle class - is shakier, and a few more words must be devoted to it. Whereas some evidence seems to suggest that MFIs can promote the short-term empowerment of their clients by helping them grow out of poverty- and debt-traps, it is by no means clear that MFIs so far have helped the rise of a stable middle class. On the contrary, microcredit is often under attack in public debates for being used to supplement household income rather than to develop new economic activities, and even when new businesses open 
thanks to microloans, they are rarely ambitious enough to, for instance, allow for the employment of people other than the loan-taker (Surowiecki 2008).

We agree that evidence so far encourages caution, and our aim is not to portray MFIs as the absolute best or most reliable means of promoting the rise of a middle class in fragile countries. However, we also do not think that MFIs' likely contribution to such an aim should be assessed only based on evidence from existing projects. As we have argued in the previous section, microfinance can only stand a chance to fulfil its empowerment aims if it is reformed in three respects.

Firstly, microfinance currently constitutes a relatively minor part of the development aid sector, whereas our argument suggests that, in virtue of being coresponsible for global political injustice, we ought to donate more in general, and devote a more substantial proportion of our donations to microfinance projects. Secondly, several current microfinance projects, especially those that rely on small NGOs and on the private sector, are volatile. Obviously, in order to achieve the desired aim of furthering the rise of a middle class, microfinance projects ought to guarantee some continuity, at least until the first evidence of a self-sustaining dynamic being triggered is in sight. Furthermore, more ambitious loans have to be made available, so as to finance small business projects that are more likely to create jobs. ${ }^{18}$ These desiderata, in turn, would be much easier to achieve with an increase in donor funds. Thirdly, and relatedly, a richer and more reliable microfinance sector is better equipped to address and monitor local and context-sensitive obstacles, such as crime infiltrations.

\footnotetext{
${ }^{18}$ For an argument along similar lines, see Surowiecki (2008). Whether this would move away from the logic of microfinance narrowly conceived and into one of "social lending" is irrelevant to our argument.
} 
More generally, MFIs can be suitably restructured so as to make them more targeted at furthering a local, productive and autonomous middle class in the medium and long run, for instance by investing in microsaving and microinsurance schemes as well as in microloans, and by assessing microloan applications in a more businesslike way - that is, looking at the intrinsic quality and promise of the proposal and not only at its poverty-relief potential.

In sum, we should be cautious in using evidence from current microfinance projects as a knock-down argument against the capacity of MFIs in principle to further a local middle class. Of course, this does not mean that the reform and development agenda we are envisaging here can be guaranteed to be successful. This, however, is a feature that MFIs share with all empowerment projects, which are necessarily more complex, long-term based, and riskier, than projects aiming at relieving immediate needs.

\subsection{Lack of Self-sustainability}

Finally, one might worry that microfinance cannot successfully combine economic self-sustainability with the aim of helping the poor: The two desiderata conflict with each other (Hermes, Lensink, and Meesters 2011). Consider the following example. Banco Compartamos (Mexico) is not only self-sustaining, but economically very successful. It started issuing shares in April 2007, in what proved to be an extremely popular public sale. The commercial success of Banco Compartamos, however, has been in large part fuelled by high interest rates. At the time the public sale took place, for instance, the total yearly interest on loans had reached 94 percent—something Yunus himself regarded as morally unacceptable (Cull, Demirgüç-Kunt, and Morduch 2009). The worry, however, is that given the high transaction costs 
involved in micro-credit, financial self-sustainability can only be obtained the "Compartamos way," namely at the high moral price of making money out of the needy.

If we take this trade-off to be a real one - thus granting our objector's premise - two possible responses seem available. One gives prominence to the commercial rationale behind microfinance, the other to its "moral" one. The former response-strategy has been defended, for instance, by The Economist. "Despite charging what may seem high interest rates," says The Economist, "MFIs typically have wafer-thin margins because of the high costs of making and collecting payments on millions of tiny loans. Pressing them to reduce rates further would jeopardise their ability to attract private capital, inhibiting their growth. Slower growth would in turn hamper their ability to harness economies of scale in order to lower transaction costs and cut rates of their own accord, as many-including the biggest for-profit MFIs - have done in the past. Forcing down rates would also deter new entrants and reduce competition" (The Economist 2010, added emphasis).

Although this response might make sense from a purely commercial standpoint, it is not one we endorse. In fact, from the perspective advanced in this chapter, we should not be deeply concerned with the trade-off between selfsustainability and poverty alleviation in the first place. In our view, the very idea that MFIs constitute the "silver bullet that will cure world poverty and spread the wealth-creating force of capitalism across the globe" (Perkins, 2008) is misguided. We have argued that supporting MFIs is a way for those who contribute to, and benefit from, an overall unjust global order to compensate the disadvantaged. Given that, on the most plausible principles of global distributive justice, some of what the wealthy currently possess is not something they are entitled to, the fact that MFIs 
might not be self-sustaining after all, or may not generate profit, is of no relevance to our moral assessment of them. Of course, it would be highly desirable if they could become self-sustaining, profitable, and serve the interests of the poor. But our support for MFIs should not be conditional on their ability to meet all of these desiderata.

To the extent that MFIs are a good second-best mechanism for addressing pressing problems of political injustice, and to the extent that we have stringent duties to address these problems, we ought to support them. Even if it were true that "non-exploitative" MFIs could not continue to exist without donations, this would not be an argument against MFIs themselves, but rather, it would be an argument in favour of continued donations. As Jonathan Morduch asks "[I]f money spent to support microfinance helps to meet social objectives in ways not possible through alternative programs like workfare or direct food aid, why not continue subsidizing microfinance?" (Morduch 1999, 1571). If the antecedent of this conditional is trueas we have cautiously suggested - then we see no reason why not.

\section{Conclusion}

In this chapter, we have argued that while supporting MFIs is not an ideal way of discharging our duties of humanity and distributive justice, it can be a good secondbest strategy for addressing global political injustice, by contributing to the rise of the middle class in fragile countries, and political empowerment as a result. To achieve this goal, MFIs have to be significantly reformed, so as to benefit from greater resource-availability, more continuity, and context-sensitivity. That said, let us conclude with a modicum of caution, by highlighting the modest reach of our argument. Our aim has been to answer this question: If you are persuaded that global 
political injustice is one of the most pressing problems of the global order, and you have no reasonable means of addressing it directly, what should you do? Our claim is that supporting suitably planned microfinance projects is likely to be a good option, bearing in mind all the usual qualifications, risks, and possible perverse incentives of development aid. 


\section{Bibliography}

Acemoglu, Daron, and James Robinson. 2012. Why Nations Fail: The Origins of Power, Prosperity, and Poverty. New York: Crown Publishing Group.

Acemoglu, Daron, and James A. Robinson. 2006. Economic Origins of Dictatorship and Democracy. New York: Cambridge University Press.

Anbarasan, Ethirajan. 2010. "Bangladesh Grameen Aid Is Probed.” BBC News, December 2. http://www.bbc.co.uk/news/world-south-asia-11899506.

Arneson, Richard J. 2000. “Luck Egalitarianism and Prioritarianism.” Ethics 110 (2): $339-49$.

Avi-Yonah, Reuven S. 2008. "Globalization and Tax Competition: Implications for Developing Countries." In Taxation and Latin American Integration, edited by Vito Tanzi, Alberto Barreix, and Luiz Villela, 173-94. Washington, D.C.: Inter-American Development Bank.

Barres, Isabelle, and Holly Lard. 2007. "Maximizing Microfinance.” Georgetown Journal of International Affairs 8 (2): 55-62.

Barro, Robert J. 1999. “Determinants of Democracy.” Journal of Political Economy 107 (6): 158-83.

Barry, Brian. 1991. "Humanity and Justice in Global Perspective.” In Liberty and Justice: Essays in Political Theory 2, 182-210. Oxford: Clarendon Press.

Barry, Christian, and Sanjay Reddy. 2008. International Trade and Labor Standards: A Proposal for Linkage. New York: Columbia University Press. Blake, Michael. 2001. "Distributive Justice, State Coercion, and Autonomy." Philosophy \& Public Affairs 30 (3): 257-96.

Bräutigam, Deborah. 2000. “Aid Dependence and Governance.” Expert Group on Development Issues 1. 
Brock, Gillian. 2009. Global Justice : A Cosmopolitan Account. Oxford: Oxford University Press.

Buchanan, Allen. 1987. “Justice and Charity.” Ethics 97 (3): 558-75.

Caney, Simon. 2005. Justice beyond Borders. Oxford: Oxford University Press.

Casal, Paula. 2007. “Why Sufficiency Is Not Enough.” Ethics 117 (2): 296-326.

Cull, Robert, Asli Demirgüç-Kunt, and Jonathan Morduch. 2009. "Microfinance

Meets the Market." Journal of Economic Perspectives 23 (1): 167-92.

Dietsch, Peter. 2011. "Rethinking Sovereignty in International Fiscal Policy." Review of International Studies 37 (05): 2107-20.

Fabre, Cécile. 2002. “Good Samaritanism: A Matter of Justice.” Critical Review of International Social and Political Philosophy 5 (4): 128-44.

Glassman, Ronald M. 1995. The Middle Class and Democracy in Socio-Historical Perspective. Leiden: Brill.

Gokhale, Ketaki. 2009. “As Microfinance Grows in India, So Do Its Rivals.” Wall Street Journal, December 16, sec. Business. http://online.wsj.com/articles/SB126055117322287513.

Grameen Communications. 1998. "Grameen Bank, Introduction.” http://www.grameeninfo.org/index.php?option=com_content\&task=view\&id=16\&Itemid=112.

Grewal, David Singh. 2008. Network Power: The Social Dynamics of Globalization. New Haven, CT: Yale University Press.

Hermes, Niels, Robert Lensink, and Aljar Meesters. 2011. "Outreach and Efficiency of Microfinance Institutions.” World Development 39 (6): 938-48.

Hulme, David. 2000. "Is Microdebt Good for Poor People?: A Note on the Dark Side of Microfinance." Small Enterprise Development 11 (1): 26-28. 
Jones, David Martin. 1998. "Democratization, Civil Society, and Illiberal Middle

Class Culture in Pacific Asia." Comparative Politics 30 (2): 147-69.

Ledgerwood, Joanna. 1998. Microfinance Handbook: An Institutional and

Financial Perspective. Washington, D.C.: World Bank Publications.

https://www.dawsonera.com/readonline/9780821384312/startPage/18.

Lippert-Rasmussen, Kasper. 2013. "Justice and Bad Luck.” In The Stanford

Encyclopedia of Philosophy, edited by Edward N. Zalta, Fall 2009. Accessed

December 7. http://plato.stanford.edu/archives/fall2009/entries/justice-badluck/.

Lipset, Seymour Martin. 1959. "Some Social Requisites of Democracy: Economic

Development and Political Legitimacy." American Political Science Review 53 (01): 69-105.

Macdonald, Terry, and Miriam Ronzoni. 2012. "Introduction: The Idea of Global Political Justice." Critical Review of International Social and Political Philosophy 15 (5): 521-33.

Mallick, Debdulal. 2012. "Microfinance and Moneylender Interest Rate: Evidence from Bangladesh.” World Development 40 (6): 1181-89. doi:10.1016/j.worlddev.2011.12.011.

Moellendorf, Darrel. 2005. "The World Trade Organization and Egalitarian Justice." Metaphilosophy 36 (1-2): 145-62.

Morduch, Jonathan. 1999. "The Microfinance Promise.” Journal of Economic Literature 37 (4): 1569-1614.

Nobel Media AB. 2014. “The Nobel Peace Prize 2006.” Nobelprize.org. http://www.nobelprize.org/nobel_prizes/peace/laureates/2006/.

Parfit, Derek. 1997. "Equality and Priority." Ratio 10 (3): 202-21. 
Perkins, Anne. 2008. “A Short History of Microfinance.” The Guardian, June 3. http://www.theguardian.com/katine/2008/jun/03/livelihoods.projectgoals1.

Pettit, Philip. 1997. Republicanism. A Theory of Freedom and Government. Oxford: Oxford University Press.

Pitt, Mark M., Shahidur Rahman Khandker, and Jennifer Cartwright. 2006. "Empowering Women with Micro Finance: Evidence from Bangladesh." Economic Development and Cultural Change 54 (4): 791-831.

Pogge, Thomas. 2002. "Moral Universalism and Global Economic Justice.” Politics, Philosophy \& Economics 1 (1): 29-58.

—. 2005. "Recognized and Violated by International Law: The Human Rights of the Global Poor." Leiden Journal of International Law 18 (04): 717-45.

—.2008. World Poverty and Human Rights: Cosmopolitan Responsibilities and Reforms. Cambridge: Polity.

Ronzoni, Miriam. 2012. "Two Conceptions of State Sovereignty and Their Implications for Global Institutional Design.” Critical Review of International Social and Political Philosophy 15 (5): 573-91.

Sanyal, Paromita. 2009. "From Credit to Collective Action: The Role of Microfinance in Promoting Women's Social Capital and Normative Influence.” American Sociological Review 74 (4): 529-50.

Sen, Amartya. 1983. Poverty and Famines. Oxford: Oxford University Press.

—1999. Development as Freedom. Oxford: Oxford University Press.

— 2000. "Democracy: The Only Way Out of Poverty." New Perspectives Quarterly 17 (1): 28-30.

Sen, Amartya, and James Foster. 1997. On Economic Inequality. New York: Oxford University Press. 
Singer, Peter. 1972. "Famine, Affluence, and Morality." Philosophy and Public Affairs 1 (3): 229-43.

—. 1999. "The Singer Solution To World Poverty." The New York Times, September 5, http://www.nytimes.com/1999/09/05/magazine/the-singersolution-to-world-poverty.html.

Steinberg, Richard H. 2002. "In the Shadow of Law or Power? Consensus-Based Bargaining and Outcomes in the GATT/WTO." International Organization 56 (02): 339-74.

Stiglitz, Joseph E. 2006. Making Globalization Work. London: Penguin.

Surowiecki, James. 2008. "What Microloans Miss.” The New Yorker, March. http://www.newyorker.com/magazine/2008/03/17/what-microloans-miss.

The Economist. 2010. "Microfinance: Leave Well Alone,” November. http://www.economicom/node/17522606.

Valentini, Laura. 2011. Justice in a Globalized World: A Normative Framework. Oxford: Oxford University Press.

- 2013. "Justice, Charity, and Disaster Relief: What, If Anything, Is Owed to Haiti, Japan and New Zealand?” American Journal of Political Science 57 (2): 491-503.

Wolff, Jonathan, and Avner de-Shalit. 2007. Disadvantage. Oxford: Oxford University Press.

Woods, Ngaire. 2006. The Globalizers: The IMF, the World Bank, and Their Borrowers. 1 edition. Ithaca, N.Y.: Cornell University Press.

Woods, Ngaire, and Amrita Narlikar. 2001. "Governance and the Limits of Accountability: The WTO, the IMF, and the World Bank." International Social Science Journal 53 (170): 569-83. 
Zeller, Manfred, and Julia Johannsen. 2008. "Is There a Difference in Poverty Outreach by Type of Microfinance Institution? Country Studies from Asia and Latin America." Savings and Development 32 (3): 227-69. 